\title{
Tests of geosynthetics-reinforced ballast stressed state under heavy trains
}

\author{
Andrei Petriaev ${ }^{1}$, and Anastasia Konon ${ }^{1, *}$ \\ ${ }^{1}$ Emperor Alexander I St. Petersburg State Transport University (PGUPS), Moskovsky pr. 9, St. \\ Petersburg, 190031, Russia
}

\begin{abstract}
Nowadays requirements for strength and stability of railway subgrade are increased. It occurs due to raising of train speed and axle load. Some sections of subgrade that were previously considered stable do not satisfy safety requirements. In this regard, superstructure reinforcing solutions need to be developed. This paper highlights ballast and subgrade reinforcement applications of geogrids in railway infrastructure. In recent years, geosynthetics are widely used for this purpose. The paper describes recent studies, which helped to identify geosynthetics reinforcement influence on ballast layer and subgrade. Influence of axial load on stress in ballast and subgrade was determined. Obtained data showed that design solutions are required to provide subgrade top bearing capacity in terms of operation with axle loads over $220 \mathrm{kN}$. Design solution is protective layers installation of polystyrene or geogrids. Five types of geosynthetic materials were placed on the top of subgrade to study vertical stresses distribution in ballast under freight train.
\end{abstract}

\section{Introduction}

Increasing of the railway subgrade bearing capacity should be done according the operation intensification of existing rail network. Firstly, it is planned to increase the weight of trains by increasing the linear load on the track and to increase the length of trains. For these purposes railway companies use heavy-duty eight-axle cars with axle load up to 250 $\mathrm{kN}$ and powerful locomotives with loads up to $270-300 \mathrm{kN} / \mathrm{axle}$.

Rolling stock and track superstructure design has undergone substantial changes in the recent years, which, of course, affected the subgrade. At the same time, subgrade design remains essentially unchanged, but its in-situ state is characterized by a decrease of the deformation properties and bearing capacity, in some cases. Monitoring of subgrade operation [1-3] has shown convincingly, that axle load and train speed increasing accelerate subgrade deterioration (track geometry problems, slope deformations). Subgrade defects in most cases are tresults of the influence of dynamic vibrational impact from passing trains on soil strength and deformation characteristics.

The implementation of planned measures causes a significant increase in the dynamic vibrational impact imposed to railway track, including the subgrade. They will increase

\footnotetext{
*Corresponding author: a.a.konon@mail.ru
} 
significantly when the eight-axle wagons and long freight trains will be introduced, due to stresses distribution zone depth increase [4-5].

Previous laboratory studies and numerical simulation results have highlighted the benefits of geosynthetics reinforcement [10-11]. These studies, as well as field investigations [6-9, $12,13]$, have also determined conditions of influence on subgrade, number of geogrid layers, cell dimensions effect on the geogrid performance. Previous studies have mostly focused on deformation characteristics of soils, reinforced by geosynthetics. However, to determine their influence on the bearing capacity of ballast and subgrade it is necessary to know the stress state in terms of moving load.

\section{Field investigations on geosynthetics-reinforced ballast}

Test was performed on two sections of the Oktyabrskaya railway line to identify vertical stresses in ballast and subgrade during passage of heavy trains.

Test section was located on a tangent track. Track structure consisted of rails R65 length $25 \mathrm{~m}$, wooden sleepers $1840 \mathrm{pcs} / \mathrm{km}$, track gauge in working section was $1520 \mathrm{~mm}$. Ballast consisted of $40 \mathrm{~cm}$ crushed stone. The embankment was composed of $1.9 \mathrm{~m}$ fine-grained sand (Fig.1). Pressure cells were used to measure stresses.

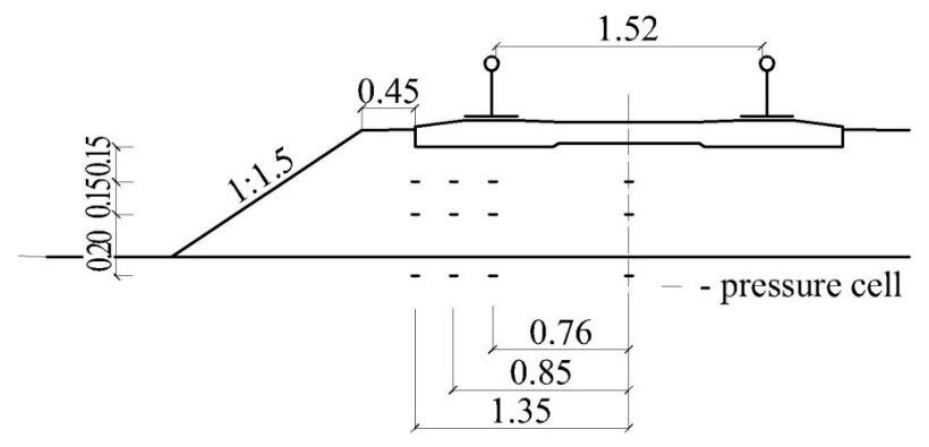

Fig. 1. Sensors installation scheme.

\section{Discussion}

Stress oscillograms were recorded during train passages with different speeds. Vertical sensors record passages of rolling stock and accurately register the bogie axles. In this connection, the stress curve is conventionally divided into the following components: full stresses $\sigma_{\mathrm{f}}$, static $\sigma_{\mathrm{st}}$ and stress of pulsation $\Delta \sigma$. In our view, static component depends in greatest extent on the linear load on the subgrade, and dynamic component characterizes the stress of pulsation from the unsprung mass, rail roughness and the surface of the wheel. The magnitude of the total stresses depends on rolling stock speed and wheel load. Total stresses magnitude rises when rolling stock speed and axle load increase, as indications of vertical pressure cells show.

With increasing depth from the sleeper pad, there is $\sigma_{\text {st }}$ magnitude decrease. Its registration duration was increased due to longer time of load application at stress measurement point. Sharp bursts of vertical stresses correspond to the wheelset passage over the sleeper. The ratio of the total vertical stress and their pulsations in the ballast at a depth of $10 \mathrm{~cm}$ from the sleepers' bottom, during passage of the rolling stock, is in the range of 0.40 to 0.45 . The ratio of $\Delta \sigma$ and $\sigma_{\mathrm{f}}$ reduced with depth increasing, making $0.30-0.35$ at 50 $\mathrm{cm}$ depth. This happens due to value increase of $\sigma_{\mathrm{st}}$ share in $\sigma_{\mathrm{f}}$ with increasing depth because of rolling stock adjacent axles impact. 
Axle load and value of rolling stock unsprung mass have great influence on the pulsations magnitude. Locomotive VL-23 unsprung mass is almost three times higher than the corresponding value of rolling stock on CRI-X-3 bogie. Passage of the locomotive VL-23 causes stress pulsations 1.5-1.7 times as much as loaded car.

Empty or not fully loaded cars cause dynamic stresses less than locomotive by $25-50 \%$. Stress arising from passenger locomotives passage are higher than ones caused by car passage by $40-50 \%$ at the level of $50 \mathrm{~cm}$ below sleeper pad. Going down the sleeper pad, there is a significant stress reduction during passenger cars passage due to their lower axial and linear load. Comparison of stress oscillograms, recorded during freight locomotives, loaded cars, gondolas and tank cars passage, has showed that stress values are nearly equal. However, with passage of freight trains, consisting of hopper cars, special carriages and wagons heavy bulk materials, on the subgrade top there are stresses in some cases superior to ones caused by VL-23 locomotive, which is result of higher axial load of this rolling stock.

Based on experimental data, maximum probable stress distribution in the subgrade indicates that train dynamic impact causes uneven stress state along the sleepers. The biggest stress values are recorded in the under-rail section. If vertical stress $\sigma \mathrm{z}$ magnitude in the underrail section at $10 \mathrm{~cm}$ below the sleeper is taken as $100 \%$, the value of these stresses under sleeper end will be up to 55-70\%. With depth increasing, there is a gradual stress equalizing along the sleeper. Therefore, vertical stresses are $65-85 \%$ of the value for underrail section at 80-90 $\mathrm{cm}$ below sleeper end.

Presence of six-axis cars with different axial loads in trains allowed obtaining the dependency of static axial load on stress in ballast layer. The dependence of stress changes in ballast and on the subgrade top on axial loads at the middle of track section, and at junction is presented in Fig. 2. This dependency is linear. Average stress values do not exceed limit $(80 \mathrm{kPa})$ for train speed more than $60 \mathrm{~km} / \mathrm{h}$ in the middle of track section for $275 \mathrm{kN}$ axle load and in the joint area for $210 \mathrm{kN}$ axle load. Obtained data show that design solutions are required to provide subgrade top bearing capacity in terms of operation with axle loads over $220 \mathrm{kN}$.

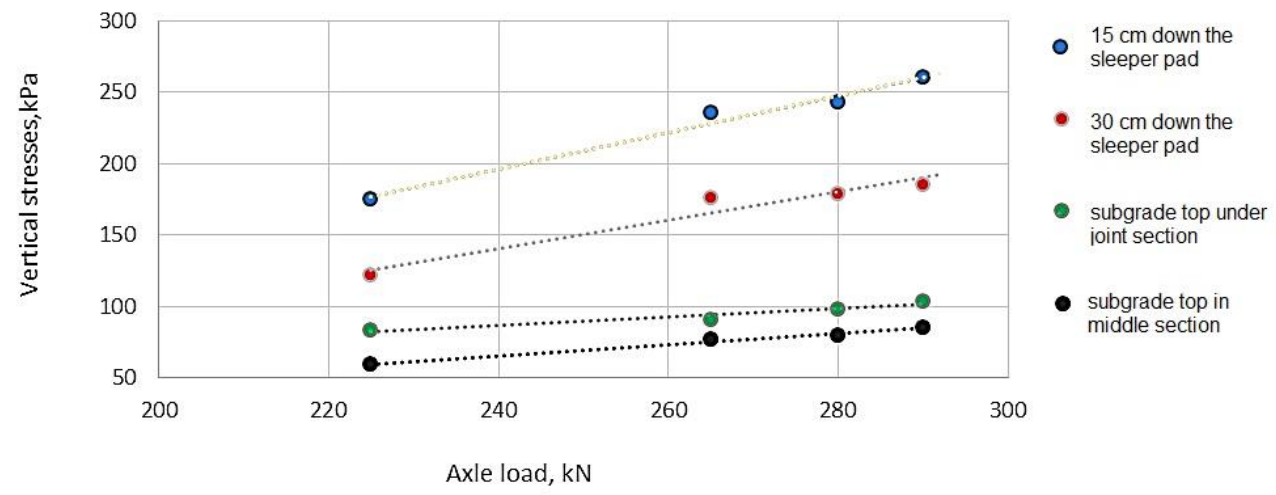

Fig. 2. Dependence of vertical stresses in the underrail cross section on axle load.

The design solution is protective layers installation of polystyrene or geogrids. In this case, the main technical solutions are the following.

Ballast needs to be cleaned to the required depth under sleeper bed with laying geogrid or XPS plates at $4 \mathrm{~m}$ width. Work is performed without removing the track by machines RM80 or SC 600 (SC 800). Cleaned ballast is laid directly on XPS plates or on geogrid, which is unwound from a roll attached to the machine pit chain (Fig.3). Roll length is $30-50 \mathrm{~m}$, the overlap of next rolls must not be less than $0.5 \mathrm{~m}$. 


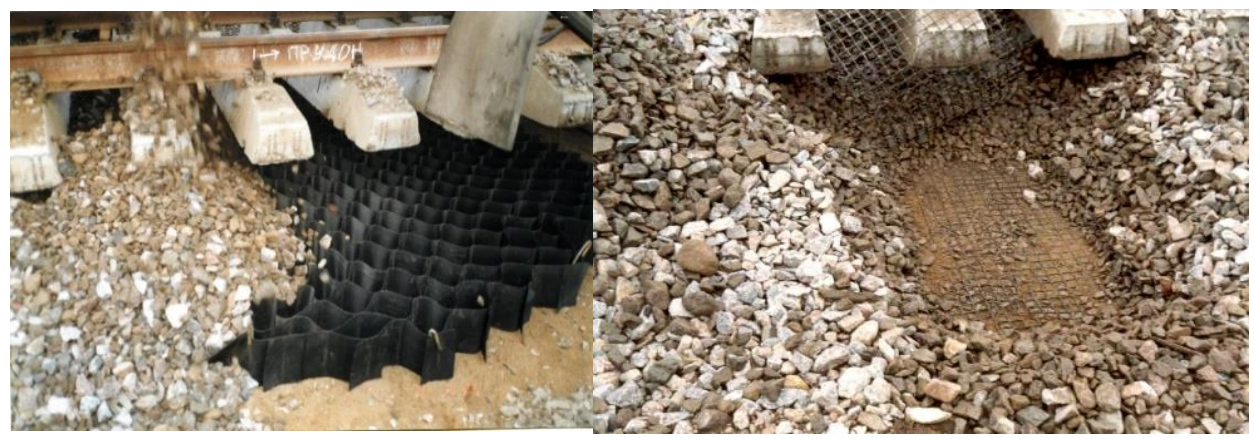

Fig. 3. Laying of geocells and two geogrid layers on the top of subgrade.

The advantage of the foresaid technical solution is its realization possibility in a complex with the overhaul or track maintenance and on the separate local area requiring reinforcement. Process of subgrade and ballast reinforcing with geogrids is combined with other works on railway subgrade improvement.

Field tests were conducted on the railway section to assess the reinforcement effect on the superstructure stress state. Geosynthetics (see Table 1) were placed on the top of subgrade during track repair on the depth of $40 \mathrm{~cm}$ below the sleeper. The following geosynthetics were used: geocells of $20 \mathrm{~cm}$ height (Type 1), a single and two layers of geogrids from different materials with $10 \mathrm{~cm}$ between layers (Type 2-4), $5 \mathrm{~cm}$ thick polystyrene plates (Type 5).

Table 1. Tested geosynthetics.

\begin{tabular}{|c|c|c|c|c|c|}
\hline $\begin{array}{l}\text { Characteristics } \\
\text { of the material }\end{array}$ & Type 1 & Type 2 & Type 3 & Type 4 & Type 5 \\
\hline Structure & Geocells & $\begin{array}{l}\text { Bi-oriented } \\
\text { geogrid }\end{array}$ & $\begin{array}{l}\text { Bi-oriented } \\
\text { geogrid }\end{array}$ & $\begin{array}{l}\text { Bi-oriented } \\
\text { geogrid }\end{array}$ & Sheet \\
\hline Polymer type & Polyethylene & Polypropylene & Polypropylene & Polyester & XPS \\
\hline $\begin{array}{l}\text { Aperture size } \\
\mathrm{MD} / \mathrm{TD}, \mathrm{mm}\end{array}$ & $200 / 200$ & $39 / 39$ & $35 / 45$ & $50 / 50$ & - \\
\hline $\begin{array}{l}\text { Strength at } 5 \% \\
\text { strain MD/TD, } \\
\mathrm{kN} / \mathrm{m}\end{array}$ & & $21 / 21$ & $28 / 30$ & $28 / 28$ & - \\
\hline $\begin{array}{l}\text { Peak tensile } \\
\text { strength } \\
\text { MD/TD, kN/m }\end{array}$ & $29 / 29$ & $30 / 30$ & $40 / 40$ & $80 / 80$ & - \\
\hline $\begin{array}{l}\text { Yield point } \\
\text { elongation } \\
\text { MD/TD,\% }\end{array}$ & $25 / 25$ & 12 & $10 / 10$ & $13 / 13$ & - \\
\hline $\begin{array}{l}\text { Compressive } \\
\text { strength at } 10 \% \\
\text { deformation, } \\
\mathrm{MPa}\end{array}$ & - & - & - & -- & 0.5 \\
\hline Density, $\mathrm{kN} / \mathrm{m}^{3}$ & - & - & - & - & 0.38 \\
\hline
\end{tabular}

Test section is a double-track main line with sandy embankments with 1.5-2.0 m height. Formation soil is peat with depth up to $6 \mathrm{~m}$. The line section is a tangent track with longwelded rails R65 and prestressed concrete sleepers.

Data analysis shows that in all cases the highest stresses were recorded at underrail section, and the smallest ones were at track center. Stresses at sleeper end have an intermediate position. 
Vertical stresses distribution under passing trains, which is shown on Fig.3, is different for different types of geosynthetics.

At track section, where ballast was reinforced by Type 1 geosynthetic, vertical stresses at under-rail cross-section were reduced by $1.5-1.8$ times. For the $50 \mathrm{~km} / \mathrm{h}$ speed of freight train, stress at control section (without reinforcement) at under-rail section was $93 \mathrm{kPa}$, for the section with Type 1 geosynthetic stress was $57 \mathrm{kPa}$, which is 1.6 times lower. At $60 \mathrm{~km} / \mathrm{h}$ speed, these values were respectively $110 \mathrm{kPa}$ and $64 \mathrm{kPa}$, which is 1.7 times lower. Similar results were obtained for 20,30, $40 \mathrm{~km} / \mathrm{h}$ train speed. In addition, stresses lowered at sleeper end compared to the control plot, but it was not as obvious, as at the under-rail cross section. At this section stresses decreased by 10-20\%. At cross-section under track center of vertical stresses decreased by 1.5-1.8 times.

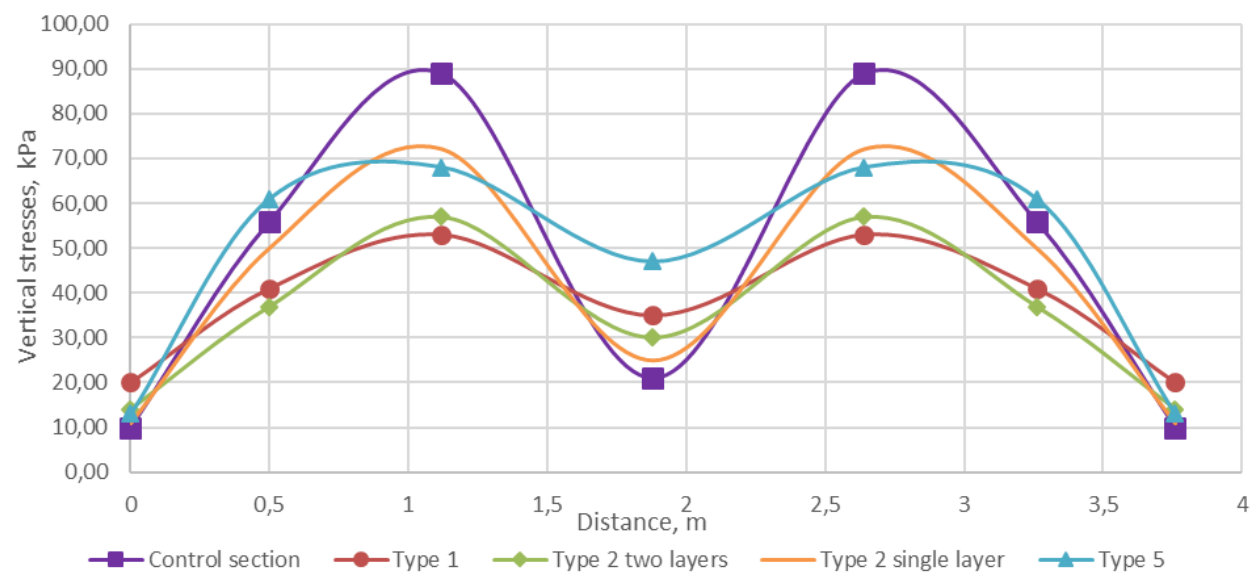

Fig. 4. Vertical stresses distribution in ballast under freight train.

At the section with two layers of Type 2 or Type 3 geogrids stresses in under-rail cross section reduced by $30-37 \%$. In this case, stresses at sleeper end cross section were also reduced. This reduction was by $20 \%$ to $43 \%$ and speed changing was from 20 to $60 \mathrm{~km} / \mathrm{h}$. At the same time stress values along track center increased in comparison with the control section. In this case, increase did not exceed $30 \%$.

One layer of Type 2, 3, 4 geogrids does not significantly reduce stresses in comparison with the control section. In this case, stresses at underrail section reduced by 5 to $25 \%$ on average. At section with one layer of Type 1 geogrid vertical stresses were fixed equal 72 $\mathrm{kPa}$, and corresponding result at control cross section was $89 \mathrm{kPa}$, which is by $24 \%$ less. For Type 2 and 3 geogrids stress values were respectively equal to $75 \mathrm{kPa}$ and $74 \mathrm{kPa}$, that is by $16 \%$ and $17 \%$ less compared with the control section with the same train speed.

At sleeper end cross section stresses decreased slightly compared to the control section. At $40 \mathrm{~km} / \mathrm{h}$ speed, stress values were up to $62 \mathrm{kPa}$ at the section by sleeper end with Type 2 geogrid, and at control section stresses were $56 \mathrm{kPa}$, which is $10 \%$ lower. Similar dependence was observed at track center cross section.

At section with Type 5 geosynthetics vertical stresses caused on top of subgrade were reduced from $89 \mathrm{kPa}$ to $68 \mathrm{kPa}(1.3-1.4$ times $)$ in terms of $40 \mathrm{~km} / \mathrm{h}$ train speed. In contrast to all of the foresaid cases, vertical stress increase by $5-10 \%$ is observed at sleeper end cross section. Stresses at track center increased significantly. In this section, they were respectively equal $37 \mathrm{kPa}, 40 \mathrm{kPa}, 46 \mathrm{kPa}$ and $48 \mathrm{kPa}$ at speeds of 20,30, 40, 50, $60 \mathrm{~km} / \mathrm{h}$, which is 2.0 2. 2 times more than at control section.

Of course, for the sake of subgrade stability the best way of loading subgrade top is uniform stress distribution. However, this is impossible to achieve, but the less will the 
difference be between stresses value at under-rail cross section, at sleeper end and at track center, the more stable will railway track be. Stress redistribution will reduce probability of local zones formation on the top of subgrade with plastic deformations, especially at underrail section. Plastic deformation zones formation lead to defects, which may further lead to loss of strength and stability of subgrade. Thus, the smoother will be the curve of stress distribution on the top of subgrade, the better will the conditions be for stable operation of railway track.

\section{Conclusions}

This paper discusses results of field studies conducted at Emperor Alexander I St. Petersburg State Transport University for enhanced track performance. The stress state of ballast and top of subgrade with different type of geosynsetics was assessed. Biaxial geogrids in ballast layer is suitable solution for increasing bearing capacity the top of substructure. Geocells and dual layer biaxial geogrids reinforcement are very effective for stresses redistribution on the subballast. The XPS plates reduce stresses on the top of subgrade and thus they demonstrate the potential performance of their usage in track. The study results allow us to recommend the geosynthetics for using as a low-cost solution to stabilize substructure.

\section{References}

1. G.M. Stoyanovich, In situ study of the dynamic vibration magnitude of the impact of a moving load on the ground (Khabarovsk, 2005)

2. V.V. Pupatenko, S.A. Kudryavtsev, E.S. Daniliants, World of transport 2, 136-142 (2008)

3. A. Petriaev, Stress states of thawed soil subgrade, Sciences in cold and arid regions 7-4, 0348-0353 (2015)

4. A.V. Petriaev, Thawing railroad bed and methods of its reinforcing, Computer methods and recent advances in geomechanics, Proceedings of the 14th international conference (2015)

5. A. Petriaev, The 3rd International Conference on Transportation Geotechnics (ICTG 2016) 143, 1136-1143 (2016) DOI: 10.1016/j.proeng 2016.06.110

6. A. Petryaev, A. Morozova, Sciences in cold and arid regions 5-5, 548-553 (2013) DOI: 10.3724/SP.J.1226.2013.00548

7. A.V. Petryaev, I.N. Zhuravlev, Modern geomaterials model tests in the laboratory, Contemporary and advanced technologies to track facilities on October Railway, Proceedings of the 43 scientific and technical conference, 119-122 (2001)

8. A.V. Petryaev, V.V Ganchits, Proceedings of the Russian Scientific and Technical Conference 1, 59-62 (2003)

9. A.V. Petryaev, I.N. Zhuravlev, Proceedings of the III International scientific-technical conference, Petersburg state transport University of Emperor Alexander I, 101-104 (2013)

10. B. Indraratna, S. Nimbalkar, C. Rujikiatkamjorn, Transportation Geotechnics 1, 171-187 (2001)

11. Y. Qian, D. Mishra, E. Tutumluer, H. A. Kazmee, Geotextiles and Geomembranes 43(4), 412-422 (2015)

12. S.K.K. Hussaini, B. Indraratna, J.S. Vinod, Transportation Geotechnics 2, 99-107 (2015) 
13. D. Mishra, Y. Qian, H. Huang, E. Tutumluer, Transportation Geotechnics 1, 188-200 (2014)

14. M. Butorina, N. Minina, P. Ivanov, A. Petryaev, Procedia Engineering 189, 352-359 (2017) doi: 10.1016/j.proeng 2017.05.056

15. A. Konon, Bearing Capacity of Roads, Railways and Airfields (BCRRA 2017) (2017)

16. P.V. Ivanov, N.N. Belyaev, A.V. Petriaev, Procedia Engineering 189, 338-345 (2017) doi: 10.1016/ j.proeng 2017.05.054

17. A. Kolos, I. Darienko, A. Konon, Procedia Engineering 189, 916-923 (2017), doi: 10.1016/j.proeng 2017.05.142

18. A. Kolos, A. Konon, Estimation of railway ballast and subballast bearing capacity in terms of $300 \mathrm{kN}$ axle load train operation, Challenges and Innovations in Geotechnics (2016) 